- Body piercing including oral sites is increasing in popularity in the Western world.

- Piercing of oral sites may lead to a number of complications some of which are

life-threatening.

- Dentists should be aware of the increasing number of patients with pierced intra-oral and peri-oral sites and should be prepared to offer advice and guidance to patients.

\title{
A complication of tongue piercing. A case report and review of the literature
}

\author{
T. Theodossy ${ }^{1}$
}

\author{
Several complications of oral piercing have been reported, some of which are life \\ threatening. A case report on tongue piercing is presented where the ventral \\ surface of the tongue healed over the barbell requiring surgical exposure.
}

Body piercing is an ancient practice. Most items come in the form of barbells, rings or studs ${ }^{1}$ and are made of gold, silver or stainless steel. Sites include the ear, nose, eyebrow, nipples, genitalia and the oral cavity. The lip is the most commonly pierced site, but tongue piercing is becoming more popular. In this case piercing was followed by complete embedding of the metal barbell on the ventral surface of the tongue requiring surgical exposure under local anaesthesia. A review of the possible complications of tongue piercing is included.

\section{CASE REPORT}

A 28-year-old female presented to the accident and emergency department 2 weeks after having her tongue pierced and a barbell placed. She was unable to take the barbell out of her tongue as it had become completely embedded.

Examination showed a metal barbell around $20 \mathrm{~mm}$ in length traversing the tongue with the metal ball clearly visible on the dorsal surface while the ventral sur-

1"Visiting Specialist Registrar, Oral and Maxillofacial Surgery, Maxillofacial Unit, University College London Hospitals NHS Trust, Mortimer Market, WC1E 6AU Correspondence to: Tamer Theodossy

E-mail: tamertheodossy@hotmail.com

\section{Refereed Paper}

Received 27.02.03; Accepted 04.03.03

๑ British Dental Journal 2003; 194: 551-552 face had completely healed over embedding the barbell.

The piercing was exposed under local anaesthetic using both sharp and blunt dissection. Manual pressure was used on the dorsal component to stabilise the barbell, define the site of the previous piercing on the ventral surface and allow removal of the barbell. The tissue under the surface of the tongue was noted to be fibrosed. The patient was given appropriate oral hygiene instructions and advised on mouth care.

\section{DISCUSSION}

Lip and tongue piercing are gaining popularity in the western world. The reasons for wearing such jewellery appear similar to the wearing of more conventional items- though most have a strong sexual connotation. ${ }^{1}$

A variety of potential complications of oral piercing have been suggested (Table 1). The most common of which are pain and swelling. Oedema of the tongue is a feature of all tongue piercing, because of the vascularity of the area, and can lead to airway compromise as a direct consequence or due to aspiration of the jewellery. ${ }^{3,4}$

Dental and oral complications included chipping or cracking of teeth, abrasions, localised gingival recession or loss of attachment as a result of constant trauma from the metal barbell. ${ }^{5-7}$ A case of galvanic current during contact between the stainless steel appliance and an extensive amalgam filling has been reported. ${ }^{5}$
Fig. 1 Barbell visible on the dorsal surface of the tongue while the ventral surface has healed over and embedded the barbell

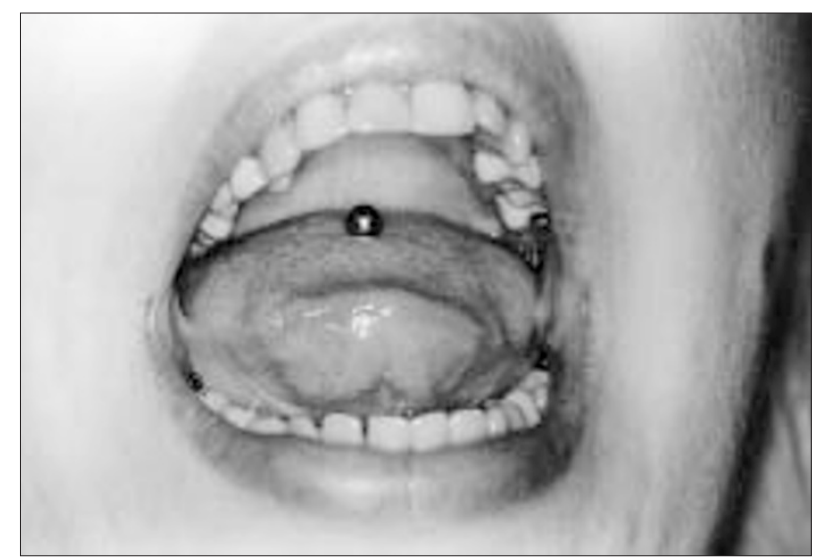


Hypersalivation, calculus build up on the lingual surface of the barbell and interference with speech, swallowing and mastication have also been reported. ${ }^{6}$

More serious complications included prolonged bleeding following tongue piercing. A case of hypotensive collapse requiring hospital admission has been reported. ${ }^{8}$

Piercing of oral sites also carries a high risk of infection with the possibility of transmission of organisms such as HIV, Hepatitis B and C, Herpes Simplex Virus, Epstein-Barr Virus and candida. Perhaps the most serious complication to date is that reported by Perkins et al. ${ }^{9}$ in which Ludwig's angina developed secondary to tongue piercing. This was not responsive to parenteral antibiotic treatment and required intubation to secure the patient's airway followed by extra-oral surgical decompression.

Practitioners of body art appear to be aware of the need for infection control. They usually wear disposable gloves and use sterile or disposable instruments and autoclaved jewellery. ${ }^{10}$

In this case failure to place a long enough barbell shank together with oedema of the tongue caused the ventral part of the tongue to completely heal over the bar-
Table 1 Complications and possible sequalae of oral piercing

- Pain

- Swelling

- Infection (bacterial, viral, fungal)

- Airway obstruction

- Bleeding

- Trauma to teeth and mucosa

- Speech impediment and swallowing problems

- Hypersalivation

- Lingual nerve damage

- Swallowed or inhaled jewellery

- Foreign body incorporation into site of piercing

- Radiographic artefact

- Calculus formation on metal surfaces

- Galvanic and hypersensitivity to metal

bell requiring surgical exposure of the tongue piercing.

Although it would appear that most tongue piercings proceed uneventfully, the severity of the complications suffered make the practice of tongue piercing one which is difficult to condone.

Dentists should be aware of the increasing number of patients with pierced intraoral and peri-oral sites and be prepared to address dental issues, such as potential damage to the teeth and gingiva and risk of oral infection, that may arise as a result of piercing. Dentists also need to provide appropriate guidance to patients who are contemplating body piercing involving oral sites.

The authors would like to thank Mr Colin Hopper for his help in preparing this manuscript.

1. Chen $M$, Scully $C$. Tongue piercing: a new fad in body art. BrDentJ 1992; 172: 87

2. Price $S S$, Lewis $M$ W. Body piercing involving oral sites. J Am Dent Assoc 1997; 128: 147-148.

3. Farah CS, Harmon D M. Tongue piercing: Case report and review of current practice. Aus Dent J 1998; 43: 387-389.

4. Keogh I J, O'Leary G. Serious complication of tongue piercing. J Laryngol Otol 2001; 115: 233-234.

5. De Moor R J G, De Witte A M J C, De Bruyne M A A Tongue piercing and associated oral and dental complications. Endod Dent Traumato/2000; 16: 232237.

6. Er N, Ozkavaf A, Berberoglu A, Yamalik N. An unusual cause of gingival recession: oral piercing. J Perio 2000; 71: 1767-1769.

7. Kretchmer M C, Moriarty J D. Metal piercing through the tongue and localized loss of attachment: a case report. J Perio 2001; 72: 831-833.

8. Hardee PS G F, Mallya L R, Hutchinson I L. Tongue piercing resulting in hypotensive collapse. Br DentJ 2000; 188: 657-658.

9. Perkins CS, Meisner J, Harrison J. A complication of tongue piercing. Br Dent J 1997; 182: 147-148.

10. Scully $\mathrm{C}, \mathrm{Chen} \mathrm{M}$. Tongue piercing (oral body art). Br J Oral Maxillofac Surg 1994; 32: 37-38. 